\title{
Co-Creation of Knowledge by the Hopi Tribe and Archaeologists
}

\section{T. J. Ferguson, Stewart B. Koyiyumptewa, and Maren P. Hopkins}

Investigation of traditional cultural properties for compliance with Sections 106 and 110 of the National Historic Preservation Act (NHPA) presents challenges for the Hopi Tribe and archaeologists. The significance of traditional cultural properties is derived from the role those places play in traditional beliefs and practices, so Hopi tribal members need to be actively involved in research that documents and evaluates these historic properties. Information derived from Hopi religious and traditional practices needs to be integrated with archaeological data and transformed into new knowledge that encompasses the terms of the NHPA. It is important for all parties to understand the epistemological basis for this co-creation of knowledge and agree on how that knowledge is used in historic preservation. In this article, we explore the co-creation of knowledge on a recent project on the Hopi Reservation to share what we have learned about how the Hopi Tribe and archaeologists collaborate to produce knowledge that is useful to tribal members and valuable for an anthropological understanding of heritage and cultural landscapes.

\section{ABSTRACT}

For two decades, the Hopi Cultural Preservation Office has worked with archaeologists to co-create knowledge about the past and document contemporary values associated with heritage sites. Much of this work has been accomplished within the framework of research mandated by the National Historic Preservation Act and National Environmental Policy Act. Here we describe a case study that illustrates the processes of this community-based participatory research, including research design, implementation of fieldwork, peer review of research findings, and reporting. The case study is a project conducted in 2014 by the Hopi Tribe in partnership with Anthropological Research, LLC, to investigate traditional cultural properties associated with an Arizona Public Service Company transmission line. The Hopi Tribe's collaborative research with archaeologists provides intellectual benefits for the management of archaeological resources and the humanistic and scientific understanding of the past.

Durante dos décadas, la Oficina de Preservación Cultural de la Comunidad Hopi (Hopi Cultural Preservation Office), ubicada en el norte de Arizona, ha trabajado con arqueólogos para aumentar el conocimiento sobre el pasado y documentar los valores contemporáneos asociados con sitios patrimoniales. Este trabajo se ha realizado en el marco de investigación dispuesto por el Acta Nacional de Preservación Histórica (National Historic Preservation Act and National Environmental Policy Act) y el Acta Nacional de Política Ambiental (National Environmental Policy Act). Nuestro estudio de caso ilustra los procesos de esta investigación participativa basada en la comunidad, incluyendo el diseño de la investigación, la ejecución del trabajo de campo, la revisión por pares de los resultados de la investigación y la presentación de informes. El presente caso de estudio es un proyecto llevado a cabo en 2014 por la tribu Hopi en colaboración con Anthropological Research, LLC, para investigar las propiedades culturales tradicionales asociadas con una línea de transmisión de Arizona Public Service Company. La investigación en colaboración con la tribu Hopi y los arqueólogos ofrece beneficios intelectuales para la gestión de los recursos arqueológicos y la comprensión humanística y científica del pasado.

Advances in Archaeological Practice 3(3), 2015, pp. 249-262

Copyright 2015@ The Society for American Archaeology

DOI: $10.7183 / 2326-3768.3 .3 .249$ 
Co-creation is a movement whose use in archaeology stems from the citizen science model employed in participatory museology (Simon 2010). As Simon describes,

Co-creative projects originate in partnership with participants rather than based solely on institutional needs. A community group may approach the museum seeking assistance to make a project possible, or the institution may invite outside participants to propose and work with staff on a project of mutual benefit. ... While co-creative and collaborative processes are often quite similar, co-creative projects start with the community as well as institutional needs [Simon 2010].

Simon provides an example of this process in terms of museum exhibits. Rather than simply declaring that the museum wants to do an exhibit on potato farmers and asking farmers to assist, museum staff ask the farmers what ideas they have for an exhibit that they would like the museum to produce with them. Simon identifies the three main reasons that cultural institutions engage in co-creative projects. These are to give voice to and be responsive to the needs of local communities, to provide a place for community engagement and dialogue, and to help participants develop skills that support their personal and community goals. Simon argues that co-creative projects give more power to community participants than other forms of collaboration.

Bollwerk and her colleagues (2015) explain that co-creation has two dimensions. The "co" denotes sharing of power and authority, while the "creation" denotes doing things in new ways that improve on past practice. Bollwerk and her colleagues argue that co-creation is congruent with current trends in public archaeology that engage people and groups outside of the archaeological profession in efforts to collect, interpret, and disseminate archaeological data and results. As such, co-creation strives to implement the civic engagement called for by Chambers (2004) and Little and Shackel (2014) in which applied archaeology is directed at helping people make decisions related to heritage resources. Research done using a co-creation approach shares many philosophical tenets with community-based participatory research but has the distinction of sometimes being situated in institutions outside of traditional communities. Regardless of where co-creation projects are situated, Simon (2010) points out that they give voice to local communities and are responsive to their needs, helping individuals develop skills to support their community.

We find co-creation to be a useful method in ethnographic research conducted for historic preservation. As anthropologists, rather than approach a tribe saying that this is the research we want to do, we let the tribe know we are interested in working with them. The tribe then identifies the project they want done and invites us to assist them with the research needed to attain their goals. We find it relatively easy to align our own research goals with those of the tribe to co-create intellectually useful and stimulating projects that simultaneously benefit archaeology and the tribe.

When applied in a cultural resource management context, a co-creation methodology can produce new knowledge about heritage resources and document the cultural values that com- munity members attach to those resources. This information is needed by tribes engaged in consultation with federal and state agencies during compliance activities associated with Section 106 of the NHPA. The Hopi Tribe embraces the research opportunities presented by the NHPA to conduct collaborative projects with archaeologists to generate information needed for Section 106 compliance and to document Hopi heritage and history (Ferguson 1996; Hopkins, Koyiyumptewa, Kuwanwisiwma, and Ferguson 2014).

The perspectives we share in this article are situated in our respective professional roles in historic preservation. Ferguson is a Professor of Anthropology at the University of Arizona in Tucson, where he also operates Anthropological Research, LLC, a research company dedicated to providing information needed for heritage management. Koyiyumptewa is a member of the Badger Clan at the Third Mesa village of Hotvela on the Hopi Reservation, where he is employed as the Tribal Archivist at the Hopi Cultural Preservation Office. He is also completing a Master's Degree in cultural anthropology at Northern Arizona University. Hopkins is Director of Research at Anthropological Research, LLC, in Tucson, Arizona, where she was the project director for the case study we discuss in this article.

\section{CASE STUDY: APS EL DORADO TRANSMISSION LINE CORRIDOR SURVEY}

The co-creation of knowledge by the Hopi Tribe and archaeologists for use in historic preservation is exemplified in a recent project undertaken for Arizona Public Service Company (APS). The El Dorado 500-kV transmission line was constructed across the Hopi Reservation in 1967 before Section 106 compliance standards were developed (Figure 1). The 25-year lease of the right-of-way for this transmission line expired in 1992, necessitating a renewal of the lease as part of a larger project involving the Four Corners Power Plant. On the Hopi Reservation, the Bureau of Indian Affairs (BIA) has a trust responsibility, or legally enforceable fiduciary obligation, to protect tribal land, assets, and resources while carrying out the mandates of federal law. The BIA thus has to approve real estate transactions, and this makes the lease renewal a federal undertaking requiring compliance with Section 106 of the NHPA.

As the project proponent, APS commissioned an archaeological survey to provide information needed for compliance with Section 110 of the NHPA (Laurila et al. 2011). APS undertook this archaeological survey proactively in collaboration with the Hopi Tribe's Cultural Preservation Office to support ongoing and future transmission line operations and maintenance activities, including vegetation management. This work was part of a much larger project that intensively surveyed the entirety of APS's transmission line system, encompassing more than 8,000 $\mathrm{km}$ of right-of-way corridors across Arizona and a portion of New Mexico. When the right-of-way renewal came up on the Hopi Reservation, the archaeological survey had already been completed, and it provided information to support the new undertaking associated with the lease renewal. APS later commissioned an ethnographic survey in support of the right-of-way renewal. We describe the ethnographic survey in this article, 


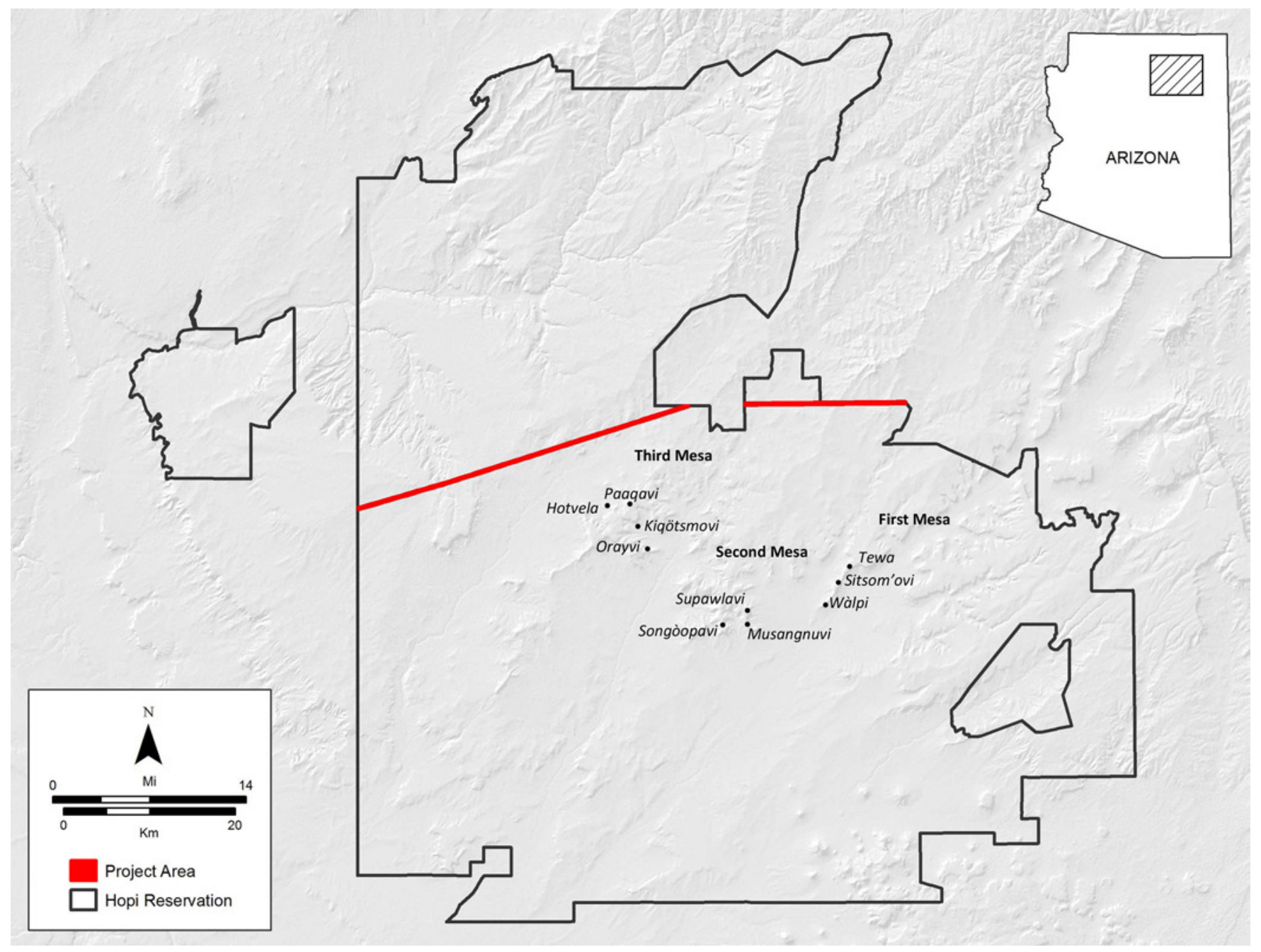

FIGURE 1. APS El Dorado 500-kV transmission line across the Hopi Reservation.

which was designed to identify traditional cultural properties and evaluate their eligibility for the National Register (Hopkins, Hedquist, Ferguson, and Koyiyumptewa 2014).

The APS right-of-way consists of a 96-m-wide easement that extends for $54.7 \mathrm{~km}$ across the Hopi Reservation. At the request of the Hopi Tribe, the Area of Potential Effect (APE) for the ethnographic study was expanded an additional $200 \mathrm{~m}$ beyond the 96-m-wide right-of-way, resulting in a study corridor that was 269 $m$ wide. The expansion of the APE for ethnographic research allowed the Hopi Tribe to better evaluate impacts of the proposed undertaking on important cultural resources.

In addition to providing information needed for compliance with the NHPA (National Park Service 2002), the ethnographic study also collected information for use in federal compliance with the National Environmental Policy Act (NEPA). The Office of Surface Mining, Department of the Interior, is preparing an Environmental Impact Statement (EIS) for the Four Corners Power Plant and Navajo Mine Energy Project, and NEPA regulations stipulate that the potential impacts of federal undertakings on historic and cultural resources must be considered. Pursuant to NEPA, environmental studies need to analyze both historic properties as defined in the NHPA and other cultural and natural resources that may not meet the technical definition of traditional cultural properties but which nonetheless have cultural importance for Hopi people.

The goals of the Hopi Cultural Preservation Office in undertaking the APS EI Dorado Transmission Line Corridor ethnographic survey were to: (1) document Hopi history as a means of heritage preservation; and (2) provide the technical services needed for compliance with federal historic preservation legislation. The project thus constituted applied archaeology in service of tribal needs to assist federal agencies with compliance with NHPA.

\section{COMMUNITY-BASED PARTICIPATORY RESEARCH}

The traditional cultural properties research undertaken to investigate the APS EI Dorado Transmission Line Corridor was organized using the principles of community-based participatory 
TABLE 1. Hopi Cultural Advisors Participating in Interviews.

\begin{tabular}{lcccc}
\hline Name & Clan & Village & Age & Date \\
\hline Lloyd Ami, Sr. & Stick-Spider & Tewa & 72 & $11 / 26 / 2013$ \\
Bradley Balenquah & Rattlesnake & Paaqavi & 73 & $11 / 27 / 2013$ \\
Riley Balenquah & Rattlesnake & Paaqavi & 71 & $11 / 27 / 2013$ \\
Floyd Lomakuyvaya & Bearstrap-Spider & Songòopavi & 64 & $11 / 26 / 2013$ \\
Harlyn Monongye & Greasewood-Roadrunner & Hotvela & 69 & $11 / 27 / 2013$ \\
Owen Numkena, Jr. & Corn-Water & Musangnuvi & 76 & $11 / 25 / 2013$ \\
Jim Tawyesva, Sr. & Roadrunner & Wàlpi & 74 & $11 / 26 / 2013$ \\
\hline
\end{tabular}

research, including recognizing the intellectual property rights of the sovereign Hopi Tribe, integrating knowledge and action for the mutual benefit of all research partners, and disseminating the findings and knowledge to all research participants (Atalay 2012; Atalay et al. 2014). As such, the APS project shares a number of similarities with collaborative research projects in the Southwest and around the world (Adler and Bruning 2008; Dowdall and Parish 2003; Heckenberger 2008; McDavid 2002; Meskell and Van Damme 2008; Shackel and Gadsby 2008; Swidler et al. 2000). In all of these projects, a group of coresearchers was formed, conditions for group learning were created, inquiry questions were researched, and group knowledge was constructed and disseminated (Bray et al. 2000). Collaborative projects provide ways for scholars to engage with local communities while maintaining the principles of scientific inquiry.

The APS project was initiated by the Hopi Cultural Preservation to serve its heritage preservation and cultural resource management goals. The Hopi Tribe set the research agenda, and the Hopi Cultural Preservation Office and Anthropological Research, LLC, established the specific research questions and project methods in a collaborative manner. The Hopi Cultural Preservation Office selected the tribal cultural experts to participate in interviews and fieldwork based on their knowledge of Hopi traditional history and the geographical areas to be investigated. Project research was conducted by Hopi staff of the Cultural Preservation Office working in collaboration with archaeologists from Anthropological Research, LLC, and this team co-wrote the project report. The tribal research participants reviewed a draft of the technical report to ensure the accuracy and appropriate use of the cultural information they had made available during the research. The Hopi Cultural Preservation Office retained control over intellectual property, including authorization of educational publications such as this article.

Inasmuch as a substantial focus of the research was directed towards identifying ancestral archaeological sites and articulating the cultural importance of these places in Hopi traditional beliefs and practices, the project was designed as a form of what Jesse Walter Fewkes (1900a:579) called "ethno-archaeology." Fewkes understood that Hopi clan traditions provide a guide for archaeologists in identifying archaeological sites in northern Arizona and in forming an anthropological understanding of Hopi ritual, language, and secular customs. Fewkes (1900a:579) noted that, "This work ... can best be done under guidance of the Indians by an ethno-archaeologist, who can bring as a preparation for his work an intimate knowledge of the present life of the Hopi villagers." The research collaborations of the Hopi Cultural Preservation Office and Anthropological Research, LLC, strive to put this research agenda into practice.

\section{PROJECT METHODOLOGY}

The specific research goals for the APS El Dorado Transmission Line Corridor survey were to: (1) locate and document traditional cultural properties; (2) evaluate the age, integrity, and significance of traditional cultural properties in terms of National Register criteria; and (3) create a written record that helps preserve Hopi traditional history and heritage. The methods used to attain these goals included conducting seven oral history interviews of tribal members representing six clans from five villages (Table 1) and fieldwork with 14 tribal members representing 14 clans from seven villages (Table 2). In total, 17 tribal members representing 17 clans from eight villages participated in the research.

The tribal members employed to conduct fieldwork were drawn from the Hopi Cultural Resources Advisory Task Team (CRATT), a body of cultural experts who represent the Hopi villages on the three mesas on the Hopi Reservation and advise the Cultural Preservation Office on matters of heritage management. Four tribal members employed by the Hopi Cultural Preservation Office and Natural Resource Office joined these cultural experts in fieldwork. Different teams of CRATT members were organized for fieldwork based on village and clan affiliation relevant to different portions of the study area. In general, CRATT members from the First Mesa villages of Wàlpi and Sitsom'ovi conducted fieldwork on the eastern portion of the study area, CRATT members from the Second Mesa villages of Songòopavi, Musangnuvi, and Supawlavi conducted fieldwork in the central portion of the study area; and CRATT members from the Third Mesa villages of Hotvela and Paaqavi conducted fieldwork in the western portion of the study area.

Interviews were conducted in the homes of tribal members, where Koyiyumptewa and Hopkins elicited information about the beliefs, knowledge, and cultural values related to the APS project area. The people interviewed ranged in age from 64 to 76 years. Interviews were conducted in Hopi and English, using a semi-structured, open-ended format beginning with standard questions to guide the discussion (Figure 2). The interviews 
TABLE 2. Hopi Cultural Advisors Participating in Fieldwork.

\begin{tabular}{|c|c|c|c|c|}
\hline Name & Clan & Village & Age & Date \\
\hline Riley Balenquah & Rattlesnake & Paaqavi & 71 & $1 / 8 / 2014$ \\
\hline Aldric George & Sand & Hotvela & 46 & $1 / 7 / 2014$ \\
\hline Steven Honanie, Jr. & Sun & Songòopavi & 59 & $12 / 3 / 2013$ \\
\hline Marvin Lalo & Tobacco-Rabbit & Wàlpi & 57 & $12 / 2 / 2013$ \\
\hline Floyd Lomakuyvaya & Bearstrap-Spider & Songòopavi & 64 & $12 / 3 / 2013$ \\
\hline Clyde Lomayaktewa & Sunforehead-Eagle & Songòopavi & 47 & $1 / 6 / 2014$ \\
\hline Herbert Masayestewa, Jr. & Spider-Bluebird & Hotvela & 72 & $1 / 7 / 2014 ; 1 / 8 / 2014$ \\
\hline Marshall Masayesva & Reed & Paaqavi & 23 & $1 / 8 / 2014$ \\
\hline Harlyn Monongye & Greasewood-Roadrunner & Hotvela & 69 & $1 / 7 / 2014 ; 1 / 8 / 2014$ \\
\hline Owen Numkena, Jr. & Corn-Water & Musangnuvi & 76 & $1 / 6 / 2014$ \\
\hline Elmer J. Satala, Sr. & Butterfly & Sitsom'ovi & 76 & $12 / 2 / 2013$ \\
\hline Leonard Talaswaima & Squash & Supawlavi & 67 & $1 / 6 / 2014$ \\
\hline Max Taylor & Sun & Songòopavi & 55 & $12 / 3 / 2013$ \\
\hline Clark W. Tenakhongva & Rabbit-Tobacco & Hotvela & 57 & $1 / 7 / 2014 ; 1 / 8 / 2014$ \\
\hline
\end{tabular}

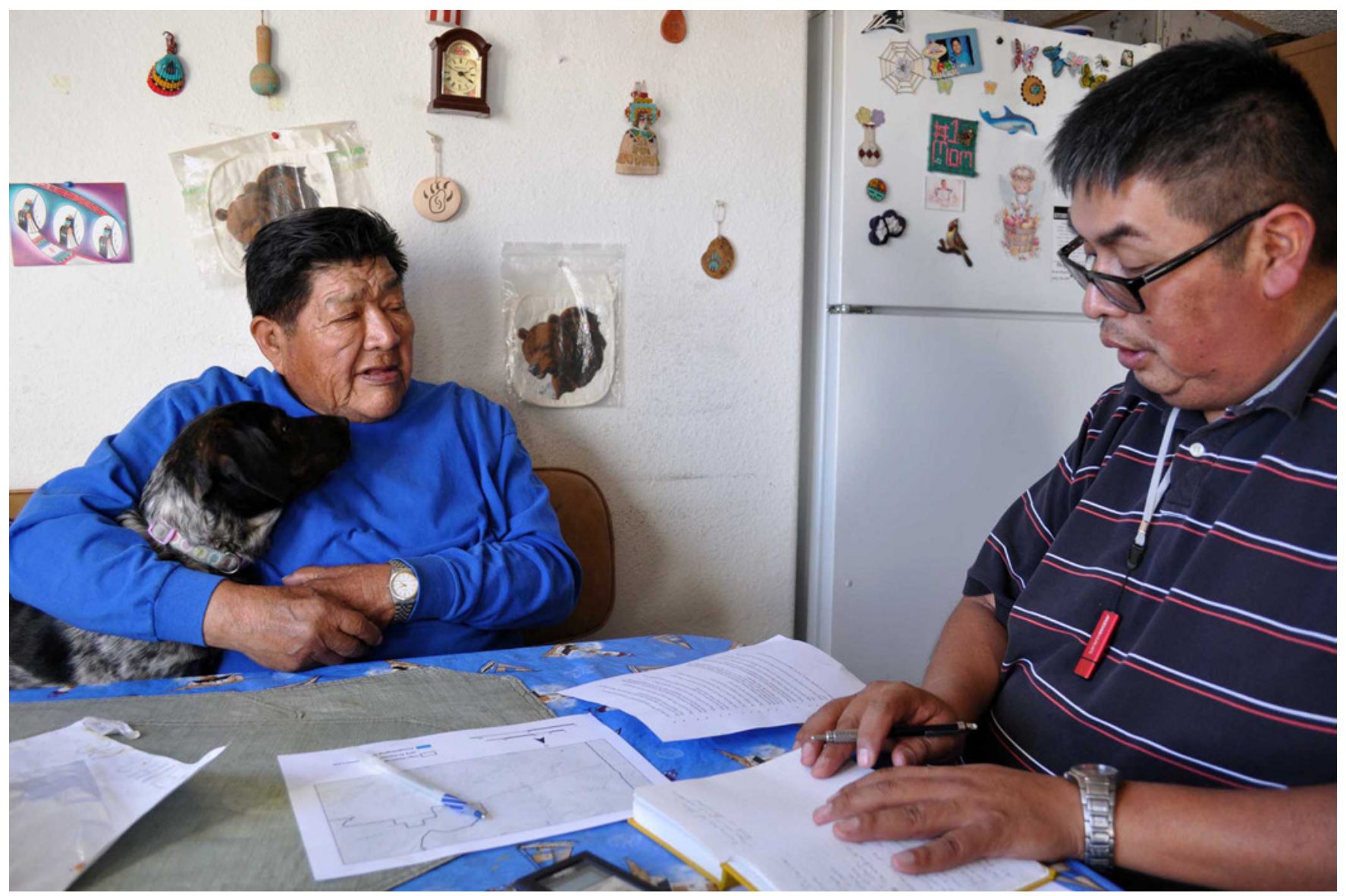

FIGURE 2. Stewart Koyiyumptewa interviewing Jim Tawyesva, Sr., at his home in Keams Canyon on the Hopi Reservation. Photograph by Maren Hopkins, November 26, 2013. 


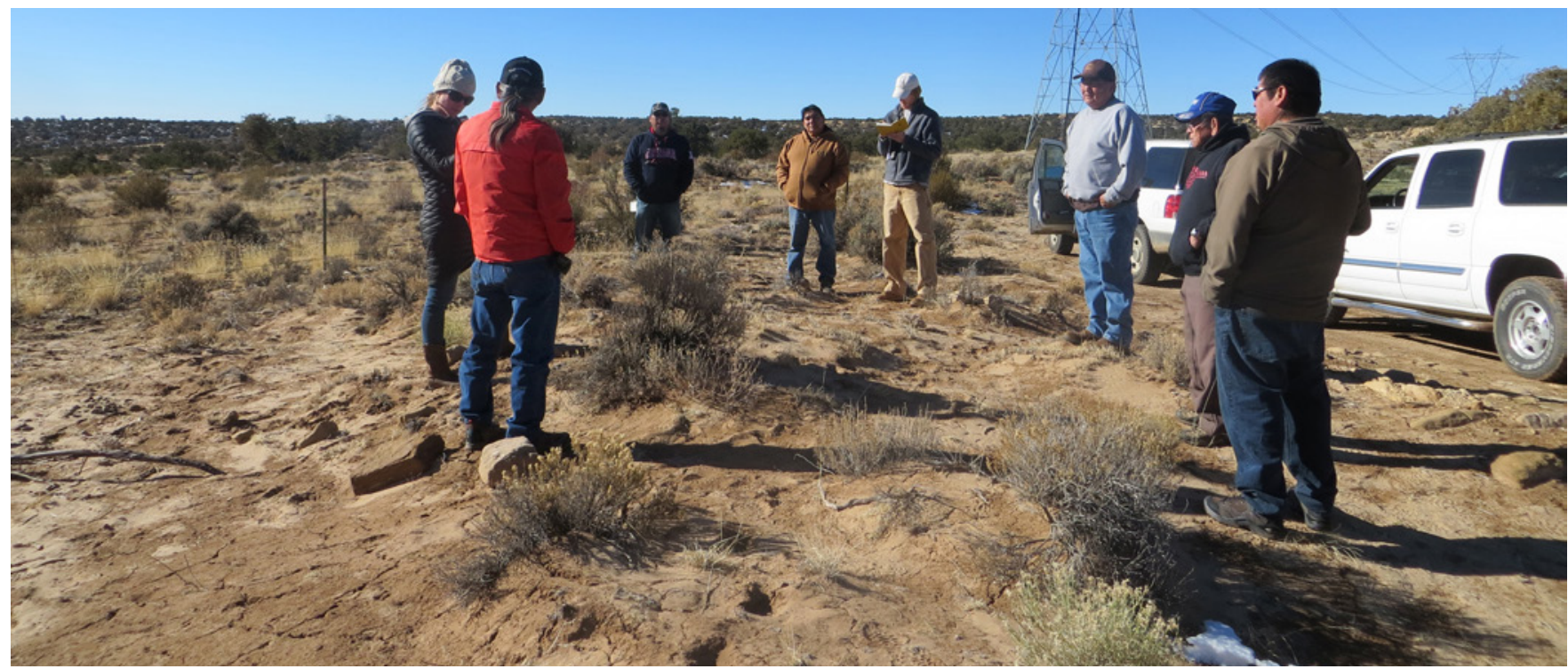

FIGURE 3. Hopi Cultural Advisors conducting fieldwork at an ancestral archaeological site in the APS study area. Photograph by T. J. Ferguson, January 6, 2014.

were recorded using a digital voice recorder. The Hopi Cultural Preservation Office hired transcribers to translate and produce written manuscripts of many of the interviews. All interview documentation, including photographs, digital recordings, and manuscripts are archived at the Hopi Cultural Preservation Office.

Fieldwork with cultural advisors included visits to ancestral sites, springs, resource procurement sites, named places, eagle collection areas, and traditional pilgrimage routes (Figure 3). These heritage resources are traditional cultural properties because they are used in the retention and transmission of Hopi culture (Ferguson et al. 1993; Kuwanwisiwma and Ferguson 2009; Parker and King 1998). Springs and shrines have traditional importance because of their role in cultural practices. Landforms, along with their toponyms, embody cultural history and didactic meaning (Hedquist et al. 2014). Plant collection areas are critical in maintaining craft production like basketry and katsina doll carving. Eagle collecting areas are associated with clan history and provide raptors used in ceremonial practices. Archaeological sites, including petroglyphs, have cultural importance because they constitute the "footprints" of the ancestors-the places where Hopi ancestors left physical evidence of their past occupation and use of land. Hopi footprints are used in teaching young tribal members about their traditional history and cultural practices. The various types of Hopi traditional cultural properties function together in the materiality of Hopi cultural practices, playing an integral role in the retention and transmission of Hopi culture from one generation to the next.

The fieldwork was designed to identify specific locations in the APS project area with significance to the Hopi people, and to situate these locations within a broader cultural, historical, and geographical context. During fieldwork, cultural advisors were asked about their knowledge of Hopi history, land use, and cultural values associated with traditional cultural properties. They also provided information needed to evaluate the National
Register eligibility of historic properties, assess potential adverse effects from the undertaking, and provide management recommendations.

\section{THEORETICAL ORIENTATION}

As befits co-creative projects, Hopi research of traditional cultural properties is informed by combining academic theories of cultural landscape with a native Hopi theory of itaakuku, or the "footprints" left behind during clan migrations to Hopi. Cultural landscapes encompass both the land itself and how individuals perceive land given their personal cultural knowledge and beliefs (Bender 1993; Sauer 1963). Hopis view landscapes in relation to specific events and historic processes that have cultural relevance. Hopi people conceptualize the land as storied landscapes in verbal discourse that has historical and moral dimensions (Ferguson and Anyon 2001; Young 1987). Named places and landscapes provide metonyms of narrative that symbolize and recall the ancient past, bringing the past into the present. Cultural landscapes thus situate Hopis in historical time and space, and the phenomenological experience of landscapes provides Hopis with a means of understanding and sharing history. There is a political dimension to cultural landscapes because control of the underlying land is an instrument of political power (Rubertone 2000; Zedeño 1997). The juncture of history, politics, social relations, and cultural perceptions entailed in landscapes infuses the land with powerful emotional attachments.

Hopis view ancestral sites and places as monuments that verify migration traditions and land stewardship (Kuwanwisiwma and Ferguson 2009). The concept of itaakuku—literally, "our footprints" - is used as a historical metaphor to comprehend the past and give meaning to archaeological sites by marking the places where ancestors traveled and lived (Ferguson and Colwell-Chanthaphonh 2006:95). Hopis interpret the archaeo- 
logical record differently from archaeologists, who define sites as discrete locales of material culture that can be physically bounded and geographically defined. In Hopi thought, archaeological sites are inextricably associated with the surrounding region. The culturally meaningful scale needed to interpret Hopi footprints thus exceeds the boundaries of archaeological sites as delineated by artifact scatters and architecture, encompassing larger landscapes. We find that conducting place-based interviews with Hopi cultural advisors, while visiting traditional cultural properties and landscapes, provides a potent means of eliciting historical and cultural information relevant to historic preservation and heritage management.

\section{RESULTS OF THE STUDY}

The traditional cultural property survey of the APS El Dorado Transmission Line Corridor was productive. During five days of fieldwork, the 14 cultural advisors we worked with identified 36 traditional cultural properties, and two additional sites that need further investigation to determine whether they are traditional cultural properties as defined in federal regulations (Table 3). Our scope of work called for assessing the eligibility of these historic properties for inclusion in the National Register of Historic Places, and we made recommendations about the significance of places based on the values articulated by Hopi cultural advisors. Historic properties are eligible for the National Register if they meet one of four eligibility criteria: (a) association with events that have made a significant contribution to the broad patterns of our history; (b) association with the lives of persons significant in our past; (c) embodiment of distinctive characteristics of a type, period, or method of construction, or the work of master, or possession of high artistic values; and (d) having yielded, or having the potential to yield, information important in prehistory or history (National Park Service 2002).

The historic properties we identified on the APS project included 26 ancestral archaeological sites, one spring, two pilgrimage trails, two mineral collection areas, and two shrines or religious offering places (Figure 4). Cultural advisors explained how these places help Hopi people retain and transmit their cultural identity from one generation to the next. To provide information needed by cultural resource managers, cultural advisors helped assess each traditional cultural property in relation to the age, integrity, and significance criteria of the National Register.

In several segments of the survey corridor, there are parallel grooves in the sandstone bedrock directly under the transmission line (Figure 5). The exact cause of these grooves has yet to be determined, although they may be related to precipitation dripping off power lines. APS is currently trying to identify how the grooves were formed. During fieldwork, cultural advisors considered how the grooves affected the cultural integrity of traditional cultural properties pursuant to NHPA and what environmental impacts they had pursuant to NEPA.

The potential adverse effects of the federal undertakingrenewing the lease for the transmission line-were discussed. Many segments of the existing roads used to access the transmission line are located outside the APS right-of-way, and cultural advisors expressed concern that traditional cultural properties may be located along the roads that were outside of the survey area. They are apprehensive that grading access roads to maintain them may damage historic properties. APS is authorized to do work only within its existing right-of-way. Any ground-disturbing activity outside the right-of-way, such as road maintenance, requires coordination with Hopi as a new project.

A full accounting of the traditional cultural properties located during the project is found in the technical report prepared by the Hopi Cultural Preservation Office (Hopkins, Hedquist, Ferguson, and Koyiyumptewa 2014). In this article, we focus on the process of co-creating knowledge by combining Hopi and archaeological points of view.

\section{THE PROCESS OF CO-CREATING KNOWLEDGE}

For more than a decade, Hopi tribal members have been involved in a long-term project to develop an indigenous archaeology (Lomaomvaya and Ferguson 2003). Co-creation in collaborative projects and community-based participatory research are important elements in this effort. Our APS project is simply another step in developing an archaeology that serves the heritage management needs of the Hopi Tribe.

In anthropological archaeology, theories are proposed to explain empirical facts and they often involve hypotheses that can be confirmed or refuted by observations that account for known data. Hopis do not require archaeological theories to comprehend their past because they have independent and highly-valued traditional sources of knowledge that are the legacy of their ancestors. For Hopis, essential information about the past is found in esoteric cultural knowledge; scientific views of the past are valuable but secondary. Anthropological theories about past human behavior that provide elegant and rational explanations in a discourse intended for academics are less important than the secure knowledge the Hopi people have inherited from their ancestors. Nonetheless, Hopis are interested in working with archaeologists because archaeological research supplements information about the past by providing details that are not generally found in traditional sources of Hopi knowledge.

We have developed a model that depicts how Hopis and archaeologists co-create knowledge for use in heritage management (Figure 6). This model was derived from self-observation and interaction with the cultural advisors working with us as we collected and analyzed information on the APS project. We discussed what we were doing and how we were doing it with the cultural advisors working with us, and they provided feedback to clarify how they saw their role in the process. The model illustrates the structural similarities and differences between Hopi and anthropological forms of knowledge.

At the base of the model are the objects of joint study. For Hopis, these are the named places and traditional use areas that are the legacy of the ancestors, the Motisinom (First People) and Hisatsinom (Ancient People). For archaeologists, these are the artifacts and physical traces that were created in the past and that continue to exist in the present for archaeological study. The overlap of these categories constitutes the Kuk'am (foot- 
TABLE 3. List of Hopi Traditional Cultural Properties Identified in the APS Project Area.

\begin{tabular}{|c|c|c|c|}
\hline No. & Site No. & Description & NRHP Eligibility \\
\hline 1 & 001-2009 (HCPO) & Ancestral habitation & $A, D$ \\
\hline 2 & 002-2009 (HCPO) & Ancestral artifact scatter & $A, D$ \\
\hline 3 & 003-2009 (HCPO) & Ancestral artifact scatter & $A, D$ \\
\hline 4 & 004-2009 (HCPO) & Tuqayva Spring & $A, C, D$ \\
\hline 5 & 005-2009 (HCPO) & Ancestral artifact scatter & $A, D$ \\
\hline 6 & 006-2009 (HCPO) & $\begin{array}{c}\text { Ancestral artifact scatter and possible historic sheepherding features or } \\
\text { hogan foundation }\end{array}$ & Undetermined \\
\hline 7 & 007-2009 (HCPO) & Possible historic sheepherding features or hogan foundation & Undetermined \\
\hline 8 & 008-2009 (HCPO) & Ancestral artifact scatter & $A, D$ \\
\hline 9 & 009-2009 (HCPO) & Ancestral artifact scatter & $A, D$ \\
\hline 10 & 010-2009 (HCPO) & Ancestral artifact scatter & $A, D$ \\
\hline 11 & 011-2009 (HCPO) & Ancestral artifact scatter & $A, D$ \\
\hline 12 & 012-2009 (HCPO) & Ancestral artifact scatter and feature & $A, D$ \\
\hline 13 & 013-2009 (HCPO) & Ancestral artifact scatter & $A, D$ \\
\hline 14 & 014-2009 (HCPO) & Ancestral habitation (Tawa'ovi) & $A, D$ \\
\hline 15 & 015-2009 (HCPO) & Ancestral artifact scatter and feature & $A, D$ \\
\hline 16 & 016-2009 (HCPO) & Ancestral artifact scatter and feature & $A, D$ \\
\hline 17 & 017-2009 (HCPO) & Ancestral artifact scatter and feature & $A, D$ \\
\hline 18 & 018-2009 (HCPO) & Historic or modern petroglyphs and feature & $A, D$ \\
\hline 19 & 019-2009 (HCPO) & Unknown, historic, or modern petroglyphs, artifact scatter, and features & A, D \\
\hline 20 & 020-2009 (HCPO) & Ancestral artifact scatter and feature & A, D \\
\hline 21 & 021-2009 (HCPO) & Ancestral habitation & A, D \\
\hline 22 & 022-2009 (HCPO) & Rock shelter & A, D \\
\hline 23 & 023-2009 (HCPO) & Ancestral artifact scatter & A, D \\
\hline 24 & 024-2009 (HCPO) & Ancestral artifact scatter and feature & A, D \\
\hline 25 & 025-2009 (HCPO) & $\begin{array}{c}\text { Ancestral artifact scatter, trail segment, offering place, and possible historic } \\
\text { sheepherding features }\end{array}$ & $A, B, C, D$ \\
\hline 26 & 026-2009 (HCPO) & Ancestral habitation; petroglyphs & $A, D$ \\
\hline 27 & 027-2009 (HCPO) & Ancestral artifact scatter and feature & $A, D$ \\
\hline 28 & 028-2009 (HCPO) & Ancestral artifact scatter & $A, D$ \\
\hline 29 & 029-2009 (HCPO) & Ancestral habitation & $A, D$ \\
\hline 30 & Isolated Feature 4 & Stone trail marker and offering place & $A, B, C, D$ \\
\hline 31 & 001-2014 (HCPO) & Ancestral habitation with stone pillars & A, C, D \\
\hline 32 & N/A & Third Mesa Kiisiw Pilgrimage Route & $A, D$ \\
\hline 33 & $\mathrm{~N} / \mathrm{A}$ & Hopi Salt Trail & $A, D$ \\
\hline 34 & N/A & Hotvela Piikyasngyam Eagle Collection Area & A, D \\
\hline 35 & $\mathrm{~N} / \mathrm{A}$ & Hotvela Tepngyam Eagle Collection Area & $A, D$ \\
\hline 36 & N/A & Hotvela Kòokyangwngyam Eagle Collection Area & $A, D$ \\
\hline 37 & N/A & Mineral collection site (qöya'owa) & $\mathrm{D}$ \\
\hline 38 & N/A & Mineral collection site (sikya'owa) & D \\
\hline
\end{tabular}




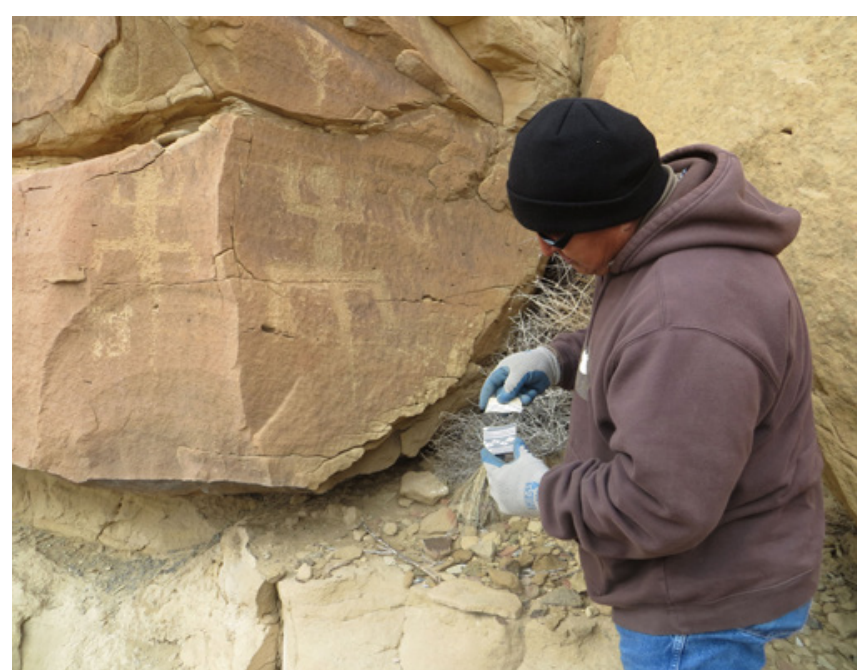

FIGURE 4. Clark W. Tenakhongva examining thirteenthcentury ancestral Hopi pottery found at Tawa'ovi, a traditional cultural property encompassing ancient architecture and petroglyphs. Photograph by T. J. Ferguson, January 7, 2014.

prints)_or archaeological record — that Hopis and archaeologists jointly examine during field research.

On the left side of the model are the categories of Hopin'voti (Hopi knowledge) that each cultural advisor uses to make sense of what he observes during fieldwork. Each advisor has a unique set of knowledge formed from clan traditions, esoteric religious teachings, and family oral histories, all of which are mediated by personal life experience. The categories of Hopi knowledge include navoti, the traditional knowledge and cultural beliefs of the Hopi people; wuqwnatovi, or religious prophecy; tutavo, the teachings, advice, and instructions one receives; maqastutavo, or forewarnings, cautionary advice, and admonitions; wimnatovi, knowledge from esoteric religious practices; and tuuwutsi, the stories, tales, legends, and fables one learns from didactic discourse. Cultural advisors use these forms of knowledge, both personal and collective, to identify and interpret named places and traditional use areas.

For instance, the eagle collecting areas of the Piikyasgyam (Young Corn Clan), Kòokyangwngyam (Spider Clan), and Tepngyam (Greasewood Clan) had been identified in earlier research with clan members who drew upon wimnavoti garnered during their personal involvement with the ritual collection of eagles (Ferguson and Lomayestewa 2007; Fewkes 1900b). This information was reconfirmed by the cultural advisors who participated in the fieldwork for the APS project, based on their understanding of navoti. Similarly, the locations where qöya'owa (a white mineral) and sikya'owa (a yellow mineral) are traditionally collected for ritual use were identified by cultural advisors based on their knowledge of wimnavoti acquired during their personal participation in cultural practices (Figure 7).

Determining what Hopi knowledge is appropriate for sharing with non-tribal members was negotiated in a series of group discussions, both informally during fieldwork and formally in

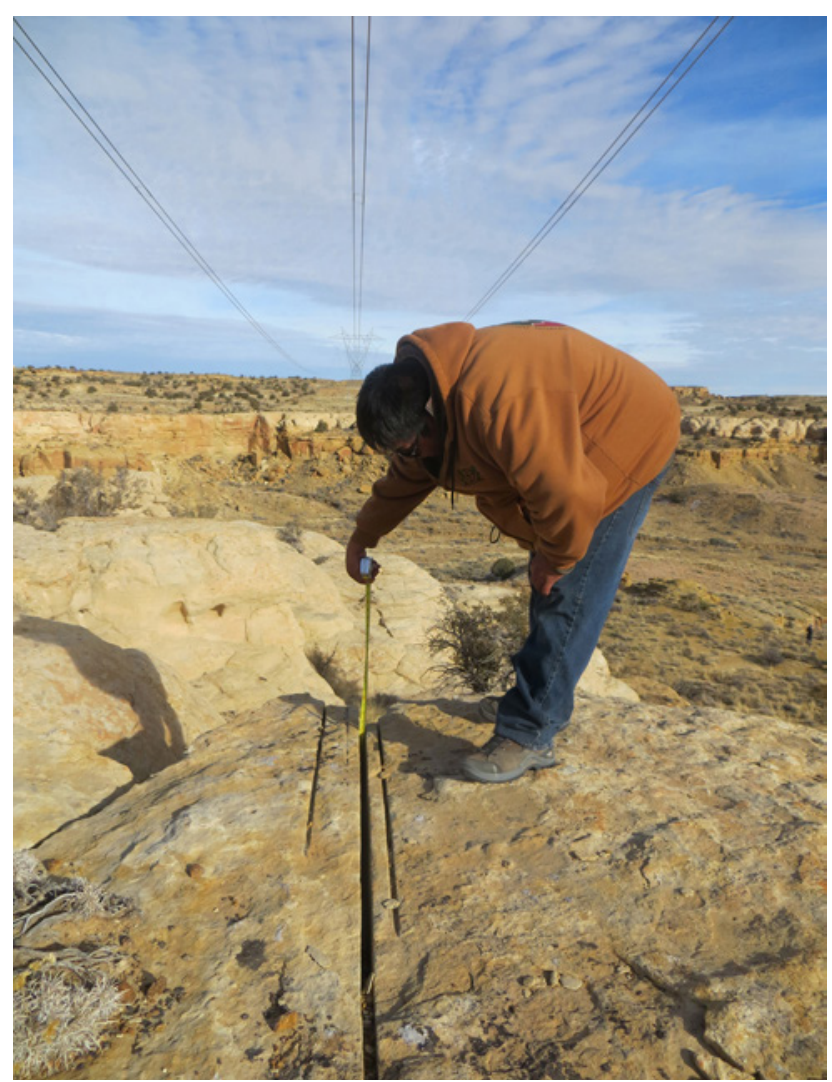

FIGURE 5. Stewart B. Koyiyumptewa measuring depth of groove in sandstone underneath transmission line. Photograph by T. J. Ferguson, January 7, 2014.

review meetings with the Hopi Cultural Resources Task Team. This insures that culturally appropriate information is released for use in heritage management.

The creation of anthropological knowledge using archaeological and ethnographic methods is depicted on the right side of Figure 6. Archaeologists working on the APS project collected and interpreted data using standard archaeological methods of making observations about the archaeological record. This information was placed in a spatial and chronological framework shaped by archaeological theories that explain the development of past groups based on the distribution of material culture.

Ethnographic research in our co-creative study, much of it done while visiting and talking about archaeological sites, was based on an analysis of the lived experiences of the cultural advisors with whom we worked. In this analysis, we took into account the social relations entailed in village, clan, and family ties, as well as the participation of cultural advisors in religious groups and other sodalities. We sought to differentiate between collective knowledge based on Hopi traditions and the oral history or personal experience of individual cultural advisors. The anthropological knowledge derived from applying archaeological and ethnological theories was then arrayed with Hopi knowledge appropriate for sharing to generate the co-created knowledge for heritage management, as presented in the technical report prepared for the project. 


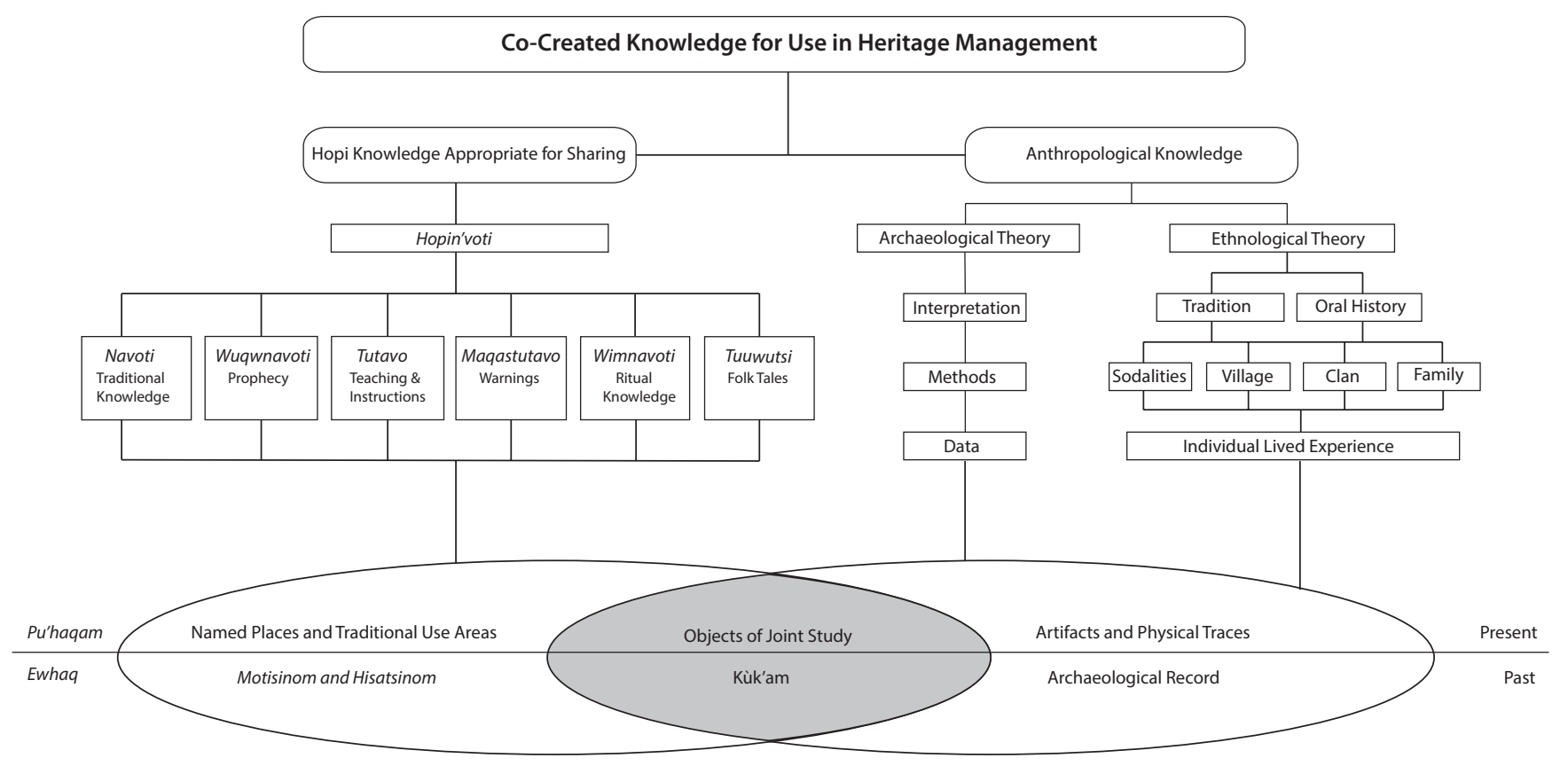

FIGURE 6. Model of co-created knowledge for use in heritage management.

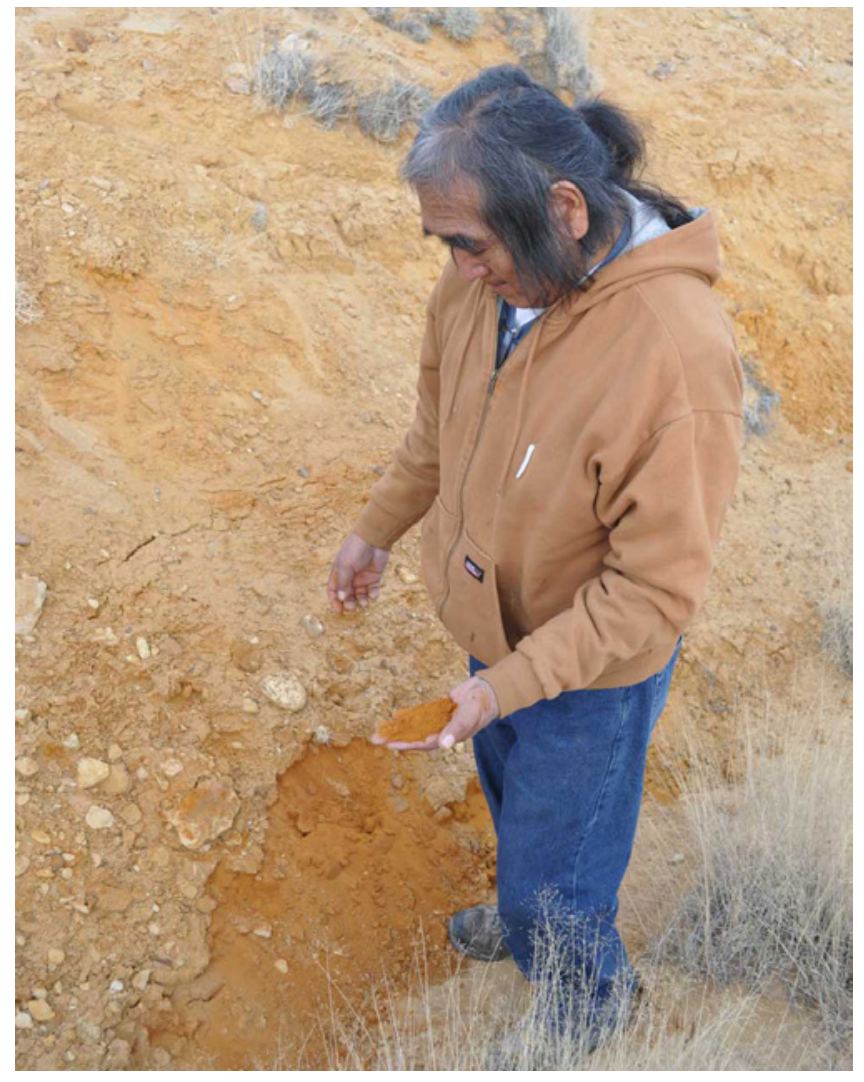

FIGURE 7. Herbert Masayestewa at source of sikya'owa, a yellow mineral he collects for use in ceremonies. Photograph by Maren P. Hopkins, January 8, 2014.

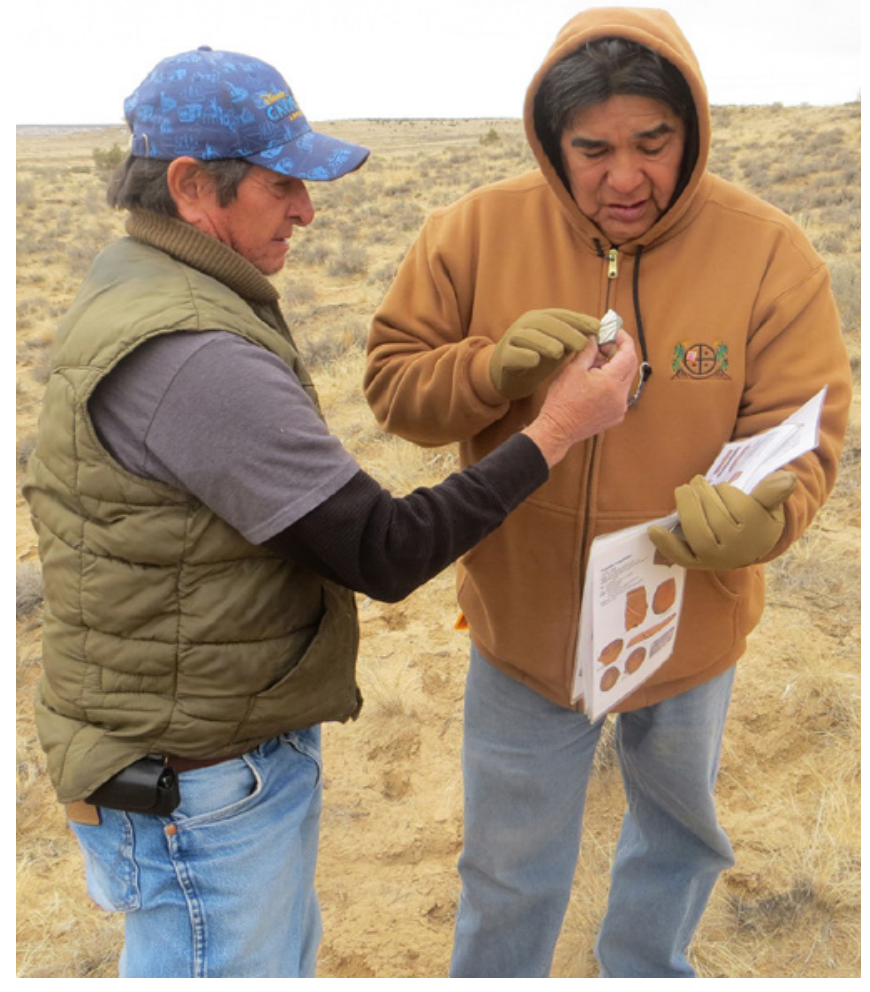

FIGURE 8. Lee Wayne Lomayestewa of the Hopi Cultural Preservation Office uses a ceramic type manual to identify the age of pottery for cultural advisor Harlyn Monongye. Photograph by T. J. Ferguson, January 7, 2014. 

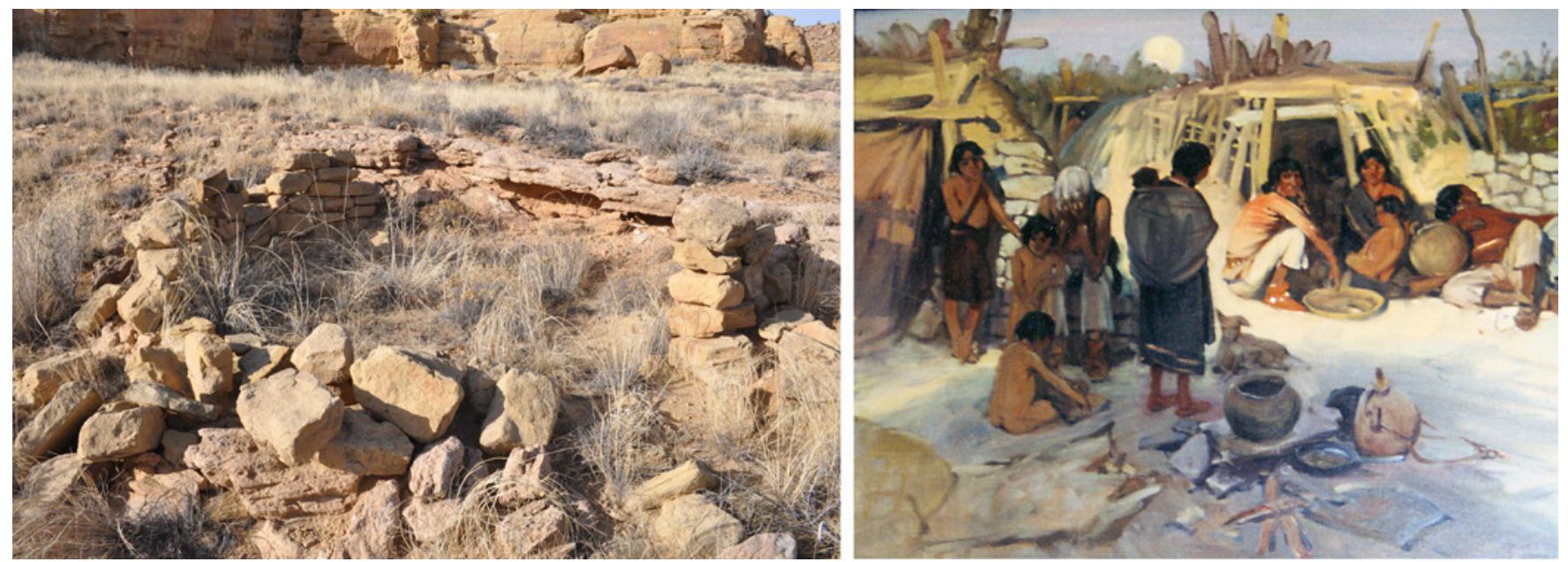

FIGURE 9. On left is a stone feature at Site 025-2009 interpreted as a Navajo Hogan during a previous archaeological survey, photographed by Maren Hopkins, January 7, 2014. On right is a Hopi homoki as illustrated in a painting by Harold Betts, courtesy of Hubbell Trading Post, National Park Service.

There is some interesting crossover in the methods that Hopis employ in co-creating knowledge. For instance, Hopi staff members of the Cultural Preservation Office use an unpublished field manual of ceramics developed by Wesley Bernadini to identify ceramic types observed in fieldwork (Figure 8). Design styles and cross-dating of ceramics provide the information needed to place ancestral sites into an absolute chronological framework that would otherwise not be possible. Using archaeological knowledge helps refine Hopin'voti and enable cultural advisors to better understand an archaeological frame of reference.

By joining Hopi knowledge and anthropological knowledge, the Hopi Cultural Preservation Office generates the information needed to identify and evaluate traditional cultural properties. This helps the Hopi Tribe to effectively engage in federally mandated historic preservation and to preserve a written record of traditional information about Hopi heritage.

\section{CHALLENGES IN THE USE OF HOPI KNOWLEDGE}

There are challenges in the co-creation of knowledge. One challenge comes from the difficulty of translating esoteric concepts into English. This is compounded by ambiguities in what knowledge is appropriate to share with people who are not initiated into Hopi religious organizations. The best way we have found to overcome this challenge is to involve the cultural advisors in a peer review of the final project report to ensure that accurate information is presented and to redact any sensitive cultural information that is not needed by federal officials in the Section 106 compliance process.

A related challenge comes from needing to decide how much information about a traditional cultural property should be revealed in technical reports for cultural resources management. Safeguards are needed to prevent the release of esoteric religious information or locational information that may put sites at risk. One solution related to linear archaeological features that we employed in the APS project was to map pilgrimage trails only where they intersected with the project APE. The pilgrimage trails were not mapped in their entirety, and the report locates only their intersection with the project right-ofway because that is the information APS needs to manage sites during maintenance activities.

\section{THE INTERPRETIVE POWER OF CO-CREATED KNOWLEDGE}

We illustrate the interpretive power of co-created knowledge with one example, although many more examples could be discussed in a longer article. A polygonal feature at Site 0252009 was originally recorded as a Navajo hogan in an archaeological survey conducted in 2009 (Laurila et al. 2011). We think this is because conventional archaeological knowledge holds that Navajos lived in polygonal structures and that Hopis lived in rectangular houses. This pattern is often discussed and is established in the literature (Jett and Spencer 1981; Mindeleff 1891). As documented in Hopi oral history, however, Hopis built homoki, polygonal structures used for temporary housing during grazing activities or times of stress, such as the period following the Orayvi split in 1906 (Hopi Dictionary Project 1998:92; Whiteley 1988). In 1906, a number of Hopis abruptly moved out of the village of Orayvi to establish new villages at Hotvela and Paaqavi. These Hopis left Oravyi in the late fall and there was not sufficient time to construct pueblo structures. They consequently constructed homoki with masonry foundations and brush superstructures to provide temporary dwellings until they could construct Pueblo room blocks (Figure 9). Similar architectural features were also constructed on the range to support sheep herding in some parts of the Hopi Reservation.

While co-created knowledge is useful in suggesting an alternative interpretation of the archaeological feature at Site 025-2009 as a Hopi rather than Navajo structure, the Hopi cultural advisors we worked with are cautious. While they believe that this structure is a Hopi feature, they advised us that archaeologists should 


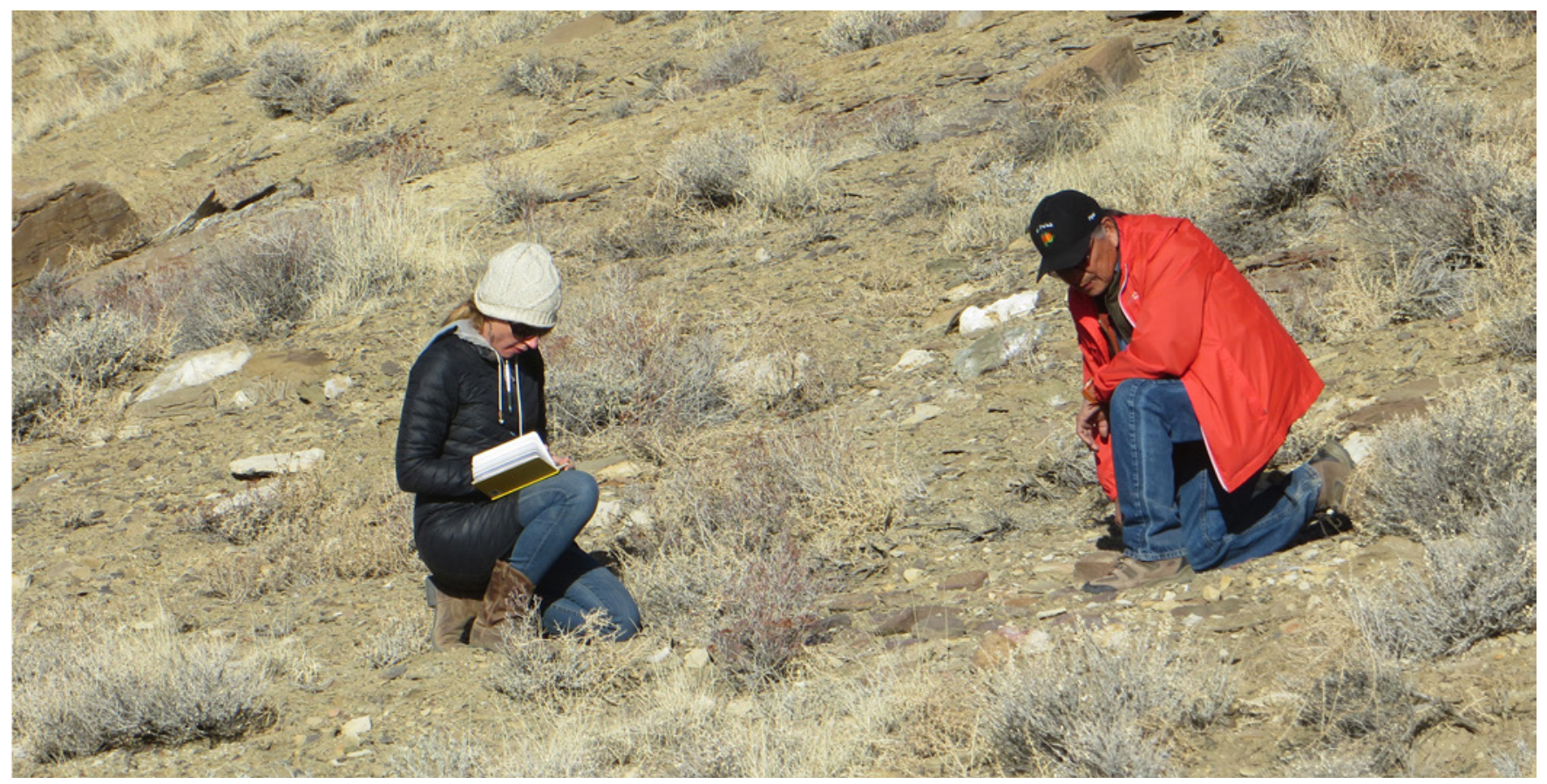

FIGURE 10. Maren Hopkins and Leonard Talaswaima discussing how archaeological features at Site 001-2014 relate to Hopi history Photograph by T. J. Ferguson, January 7, 2014.

consider this as a hypothesis for testing. If adverse effects to the site from the federal undertaking cannot be avoided, Hopi advisors recommend that additional research be conducted to investigate the cultural associations of the site and its features.

\section{CONCLUSION: THE VALUES OF CO-CREATED KNOWLEDGE}

In conclusion, we think that the co-created knowledge produced by the Hopi Tribe and archaeologists for use in heritage preservation benefits all the participants (Figure 10). The Hopi Tribe benefits from the co-created knowledge by using it in the historic preservation process to try to protect important cultural sites and learn more about them. This is particularly important with respect to sites that are not specifically referred to in oral traditions but that are nonetheless considered to be Hopi footprints. The individual Hopi research participants benefit from the co-creative project by increasing their personal knowledge and experience of heritage sites and sharing this information with other tribal members. Archaeologists benefit from an increased understanding of Hopi views of archaeological sites and cultural places and knowledge of how these places are used to construct cultural landscapes. The co-created knowledge helps interpret archaeological sites and to build anthropological theory. Everyone who participated in the project-tribal members and non-Indian archaeologists-learned new things that are important to their understanding of Hopi heritage, and the project built individual capacities for continuing the development of indigenous archaeology in future work.

In evaluating co-creative projects, both process and product need to be assessed (Simon 2010). In the APS EI Dorado
Transmission Line Corridor Survey project, the products are easy to assess. A technical report was completed and used by the Hopi Tribe in heritage management, and that work led to the publication of this article. However, we think that the process of conducting the research was as important as the products that resulted from the project. We know that the Hopi cultural advisors who participated in fieldwork returned home and shared the knowledge of what they learned with their families and, probably, with their peers during discussions in their kivas and other settings. While difficult to measure, in a society whose knowledge traditions are based in oral transmission, the discursive dissemination of what Hopi cultural advisors learned about the places that help constitute their heritage should not be discounted.

Our project met the fundamental goals of co-creation articulated by Simon (2010). We gave voice to the Hopi people, who articulated why traditional cultural properties in the project area were important. The project was responsive to the needs of the Hopi Tribe by producing a technical report that could be used in the Section 106 compliance process. The project helped individuals develop the skills needed to support their community, including the skills developed by the Hopis employed by the Hopi Cultural Preservation Office and the skills developed by a graduate student we employed to assist in the research. We think that the success of our APS project is due in part to the long-term working relationship between project archaeologists and tribal research participants. The foundation of trust needed for this type of research takes considerable time and effort to develop. While our project methodology may not be immediately transferrable to other projects, we nonetheless think it provides a model that other archaeologists and tribes can draw upon to structure research. 


\section{Acknowledgments}

We thank the Hopi cultural advisors we worked with on the APS El Dorado Transmission Line Corridor Survey for their generosity in sharing cultural information and guiding its appropriate use in heritage management. Leigh J. Kuwanwisiwma, Lee Wayne Lomayestewa, and Joel Nicholas of the Hopi Cultural Preservation Office, and Saul L. Hedquist of Anthropological Research, LLC, participated in fieldwork, and we thank them for their help in shaping our ideas about the co-creation of knowledge. We acknowledge the support of Arizona Public Service Company in funding the research, and the assistance of APS Four Corners Plant Project Manager Richard Grimes. We especially thank APS Archaeologist Jon Shumaker for reviewing and commenting on a draft of this article, and Elizabeth Bollwerk and Robert Connolly for their work as guest editors of the issue of Advances in Archaeological Practice that includes this article.

\section{Data Availability Statement.}

All field notes and copies of photographs are archived at the Hopi Cultural Preservation Office, the Hopi Tribe. For access, call (928) 734-3611 or write to Director, Hopi Cultural Preservation Office, P.O. Box 123, Kykotsmovi, AZ 86039.

\section{REFERENCES CITED}

Adler, Michael, and Susan Bruning

2008 Navigating the Fluidity of Social Identity: Collaborative Research into Cultural Affiliation in the American Southwest. In Collaboration in Archaeological Practice, edited by Chip ColwellChanthaphonh and T. J. Ferguson, pp. 35-54. AltaMira, Lanham, Maryland.

Atalay, Sonya

2012 Community-Based Archaeology: Research With, By, and For Indigenous and Local Communities. University of California Press, Berkeley.

Atalay, Sonya, Lee Rains Clauss, Randall H. McGuire, and John R. Welch

2014 Transforming Archaeology: Activist Practices and Prospects. Left Coast Press, Walnut Creek, California.

Bender, Barbara

1993 Introduction, Landscape-Meaning and Action. In Landscape Politics and Perspectives, edited by Barbara Bender, pp. 1- 17. Berg, Oxford.

Bollwerk, Elizabeth, Robert Connolly, and Carol McDavid

2015 Co-Creation and Public Archaeology. Advances in Archaeological Practice 3:178-187.

Bray, John N., Joyce Lee, Linda L. Smith, and Lyle Yorks 2000 Collaborative Inquiry in Practice. Sage, Thousand Oaks, California.

Chambers, Erve J.

2004 Epilogue: Archaeology, Heritage, and Public Endeavor. In Places in Mind: Public Archaeology as Applied Anthropology, edited by Paul A. Shackel and Erve J. Chambers, pp. 193-208. Routledge, New York.

Dowdall, Katherine M., and Otis O. Parrish

2003 A Meaningful Disturbance of the Earth. Journal of Social Archaeology 3:99-133.

Ferguson, T. J.

1996 Native Americans and the Practice of Archaeology. Annual Review of Anthropology 25:63-79.
Ferguson, T. J., and Roger Anyon

2001 Hopi and Zuni Cultural Landscapes: Implications of History and Scale for Cultural Resources Management. In Native Peoples of the Southwest, edited by Laurie Weinstein, pp. 99-122. Bergin and Garvey, Westport, Connecticut.

Ferguson, T. J. and Chip Colwell-Chanthaphonh

2006 History Is in the Land: Multivocal Tribal Traditions in Arizona's San Pedro Valley. University of Arizona Press, Tucson.

Ferguson, T. J., Kurt Dongoske, Leigh Jenkins, Mike Yeatts, and Eric Polingyouma

1993 Working Together, the Roles of Archeology and Ethnohistory in Hopi Cultural Preservation. CRM 16, Special Issue:27-37. Electronic document, http://npshistory.com/ newsletters/crm/crm-v16-special.pdf, accessed March 26, 2015.

Ferguson, T. J., and Lee Wayne Lomayestewa

2007 Kwaatu: Collection and Use of Golden Eagles on the Hopi Indian Reservation. Manuscript on file, Hopi Cultural Preservation Office, Kykotsmovi, AZ.

Fewkes, Jesse Walter

1900a Tusayan Migration Traditions. In 19th Annual Report of the Bureau of American Ethnology for the Years 1897-1898, Pt. 2, pp. 573-634. Government Printing Office, Washington, D.C.

1900b Property-Right in Eagles among the Hopi. American Anthropologist 2:690-707.

Heckenberger, Michael J.

2008 Entering the Agora: Archaeology, Conservation and Indigenous Peoples in the Amazon. In Collaboration in Archaeological Practice, edited by Chip Colwell-Chanthaphonh and T. J. Ferguson, pp. 243-272. AltaMira, Lanham, Maryland.

Hedquist, Saul L., Stewart B. Koyiyumptewa, Peter M. Whiteley, Leigh J. Kuwanwisiwma, Kenneth C. Hill, and T. J. Ferguson

2014 Recording Toponyms to Document the Endangered Hopi Language. American Anthropologist 116:324-331.

Hopi Dictionary Project

1998 Hopi Dictionary/Hopiikwa Lavàytutuveni: A Hopi-English Dictionary of the Third Mesa Dialect. University of Arizona Press, Tucson.

Hopkins, Maren P., Saul L. Hedquist, T. J. Ferguson, and Stewart B. Koyiyumptewa

2014 Talwi'pikit Tuuwuhiyat Ang Hopit Navoti'at: Hopi Traditional Knowledge on the Arizona Public Service 500kV El Dorado Transmission Line. Hopi Cultural Preservation Office, Hopi Tribe, Kykotsmovi, Arizona.

Hopkins, Maren P., Stewart B. Koyiyumptewa, Leigh J. Kuwanwisiwma, and T. J. Ferguson

2014 Comprehending Hopi Footprints: Hopi History and Traditions at Glen Canyon National Recreation Area and Rainbow Bridge National Monument. Paper presented at the Arizona Archaeological Council Fall Conference, Arizona Museum of Natural History, Mesa, Arizona, November 7, 2014.

Jett, Stephen C., and Virginia E. Spencer

1981 Navajo Architecture: Forms, History, Distributions. University of Arizona Press, Tucson.

Kuwanwisiwma, Leigh J., and T. J. Ferguson

2009 Hopitutskwa and Ang Kuktota. In The Archaeology of Meaningful Places, edited by Brenda J. Bowser and María Nieves Zedeño, pp. 90-106. University of Utah Press, Salt Lake City.

Laurila, Erick M., David A. Bild, and Erin Davis

2011 A Cultural Resources Survey of 34 Miles (927 Acres) of Hopi Tribal Lands for the Arizona Public Service Company 500-1 (Four Corners-Moenkopi-El Dorado) 500-kV Transmission Line, Coconino and Navajo Counties, Arizona. LSD Technical Report No. 075107 (500-1e), Logan Simpson Design Inc., Tempe, Arizona. 
Little, Barbara J., and Paul A. Shackel

2014 Archaeology, Heritage, and Civic Engagement. Left Coast Press, Walnut Creek, California.

Lomaomvaya, Micah, and T. J. Ferguson

2003 Hisatqasit Aw Maamatslala_Comprehending our Past Lifeways: Thoughts about a Hopi Archaeology. In Indigenous People and Archaeology, edited by G. Oetelaar, T. Peck, and E. Siegfried, pp. 43-51. Proceedings of the Chacmool Conference, University of Calgary, Canada.

McDavid, Carol

2002 Archaeologies That Hurt; Descendants that Matter: A Pragmatic Approach to Collaboration in the Public Interpretation of African-American Archaeology. World Archaeology 34:303-314.

Meskell, Lynn, and Lynette Sibongile Masuku Van Damme

2008 Heritage Ethics and Descendant Communities. In Collaboration in Archaeological Practice, edited by Chip ColwellChanthaphonh and T. J. Ferguson, pp. 131-150. AltaMira, Lanham, Maryland.

Mindeleff, Victor

1891 A Study of Pueblo Architecture in Tusayan and Cibola. In Eighth Annual Report of the Bureau of Ethnography for the Years 1886-1887, pp. 573-633. Government Printing Office, Washington, D.C.

National Park Service

2002 How to Apply the National Register Criteria for Evaluation. National Register Bulletin 15, U.S. Department of the Interior. Electronic document, http://www.nps.gov/nr/publications/ bulletins/nrb15/, accessed November 8, 2014.

Parker, Patricia L., and Thomas F. King

1998 Guidelines for Evaluating and Documenting Traditional Cultural Properties. National Register Bulletin 38. U.S. Government Printing Office, Washington, D.C.

Rubertone, Patricia E.

2000 The Historical Archaeology of Native Americans. Annual Review of Anthropology 29:425-446.

Sauer, Carl

1963 The Morphology of Landscape. In Land and Life: A Selection of the Writings of Carl Sauer. University of California Press, Berkeley.
Shackel, Paul A., and David A. Gadsby

2008 "I Wish for Paradise": Memory and Class in Hampden, Baltimore. In Collaboration in Archaeological Practice, edited by Chip Colwell-Chanthaphonh and T. J. Ferguson, pp. 225-242. AltaMira, Lanham, Maryland.

Simon, Nina

2010 The Participatory Museum. Museum 2.0, Santa Cruz. Electronic document, http://www.participatorymuseum.org/ read/, accessed March 26, 2015.

Swidler, Nina, David C. Eck, T. J. Ferguson, Leigh J. Kuwanwisiwma, Roger Anyon, Loren Panteah, Klara Kelley, and Harris Francis

2000 Multiple Views of the Past: Integrating Archaeology and Ethnography in the Jeddito Valley. CRM 23(9):49-53. Electronic document, http://npshistory.com/newsletters/crm/crm-v23n9. pdf, accessed March 26, 2015.

Whiteley, Peter

1988 Deliberate Acts. University of Arizona Press, Tucson.

Young, Jane M.

1987 Toward an Understanding of "Place" for Southwestern Indians. New Mexico Folklore Record 16:1-13.

Zedeño, María Nieves

1997 Landscapes, Land Use, and the History of Territory Formation: An Example from the Puebloan Southwest. Journal of Archeological Method and Theory 4:67-103.

\section{AUTHOR INFORMATION}

T. J. Ferguson University of Arizona, 6655 W. Sweetwater Dr., Tucson, AZ 85641

Stewart B. Koyiyumptewa $\square$ Hopi Cultural Preservation Office, P.O. Box 215 Kykotsmovi, AZ 86039

Maren P. Hopkins Anthropological Research, LLC, 19461 S. Sonoita Hwy., Vail, AZ 85641 